\title{
Pétrir la pâte, malaxer du sens. Exemples kabyles
}

\section{Marie Virolles-Souibès}

\section{OpenEdition}

\section{Journals}

Édition électronique

URL : https://journals.openedition.org/tc/786

DOI : $10.4000 /$ tc. 786

ISSN : 1952-420X

\section{Éditeur}

Éditions de l'EHESS

\section{Édition imprimée}

Date de publication : 1 février 1990

ISSN : 0248-6016

\section{Référence électronique}

Marie Virolles-Souibès, «Pétrir la pâte, malaxer du sens. Exemples kabyles », Techniques \& Culture [En ligne], 13 | 1990, mis en ligne le 16 janvier 2006, consulté le 29 septembre 2022. URL : http:// journals.openedition.org/tc/786 ; DOI : https://doi.org/10.4000/tc.786

Ce document a été généré automatiquement le 29 septembre 2022.

Tous droits réservés 


\title{
Pétrir la pâte, malaxer du sens. Exemples kabyles
}

\author{
Marie Virolles-Souibès
}

